\title{
COMPLETION OF CONTRACTS BY MAIL OR
}

\section{TELEGRAPH.}

The determination of the time when and the place where the factors which make up a contract merge in the contract itself is important for manifold reasons. For instance, it determines the moment when neither party can retract without the consent of the other, the moment when a chattel ceases to be the property of one and becomes the property of another, and so free from the obligations of the one and.subject to the obligations of the other,|no longer at the risk or charge of the one but solely at that of the other.

The place where the contract is consummated determines the rule (lex loci) which must often decide its interpretation and its legality.

A contract, like a man, is generally a citizen of the country, not in which it was begotten, but in which it was born.

The considerations above often determine the liability for taxes or other liens and charges incident to the ownership of property, the possession of an insurable interest and the right to maintain an action with reference to the property in question.

As a natural result the subject has been much mooted in the courts, and yet some simple questions which, in the nature of things, it would seem, must have frequently arisen for generations past were not settled until well on in the present century and many are among the recent additions to the settled propositions of contract law among English-speaking men.

The rules which have seemed to crystallize out of the mists and conflicts of the earlier discussions are, in the main, satisfactory and consistent. It is interesting in teaching "the law of contracts," to see how well it seems to satisfy the sense of justice of the abler and more earnest students. They often try, I learn, on reading the statement of a case, to forecast the decision, and find themselves seldom astray in this branch of the law.

The process of the courts has been rather simple. A contract is analyzed into an offer and an acceptance. The 
offer is no contract. It is only when an unqualified acceptance meets an offer still outstanding that a contract resuits, but, on such a meeting, the contract springs into existence, like Minerva from the brow of Jove, full panoplied eo instante. At that moment, in that place, the contract comes into being and must operate and be judged accordingly. Applying these rules it might seem easy to determine when and where a contract by correspondence is concluded, but the decision in individual cases has been often difficult and by divided courts, and the controversy over the question has been eager and unyielding among text writers and reviewers.

In 1818 the Court of King's Bench decided the much cited case of Adams v. Lindsell, I Barn. \& Alderson 68 I, passing upon a claim for the non-delivery of wool, where defendants had sent by post to plaintiffs, in a neighboring county, offering 800 tods of fleeces of a certain quality at a named price, "receiving your answer in course of post." The offer was delayed by a misdirection. An answer accepting was sent by post the same evening the offer arrived. This answer, it was held, closed the contract the moment it was posted, and as the delay in replying was due to the defendant's negligence in a misdirection, it was held it could not prejudice plaintiff's rights. That a sale to others, on not getting the expected reply, would not relieve the defendant. The court said: "For if the defendants were not bound by their offer when accepted by the plaintiff till the answer was received, then the plaintiff ought not to be bound till after they had received the notification that the defendants had received their answer and assented to it. And so it might go on ad infinitum."

This doctrine received no material addition in England until the House of Lords decided, in 1848, Dunlop v. Higgins, $\mathrm{IH}$. of Lds. Cases $38 \mathrm{r}$. The facts there passed on were that after some correspondence which had resulted in an offer of iron on certain terms from Dunlop, Messrs. Higgins immediately mailed a reply, "We will take the 2,000 tons you offer us." By mistake this reply was dated a day later than its true date, but the postmark showed it was mailed in due season. It was held to be an unconditional acceptance put in the post office in due time and that the contract was consummated 
the instant it was posted, and the one mailing was in no way responsible for any casualties in the post-office establishment as for a delay in its delivery.

In this case the Lord Chancellor, in his opinion, quoted very freely from the preceding case and logically applied its doctrine.

In 1872 there was decided In Re Imper. Land Co. of Marseilles, Harris Case, Law Reports 7 Chan. Ap. 587, where Mr. Harris, of Dublin, had sent to the directors of the above company at London a letter asking for 200 shares, or any smaller amount, in the above company. One hundred shares were allotted him and a notification mailed to him on the fifteenth or on the sixteenth of March, very early in the morning. A letter was sent by him to the company, mailed on March 16 , saying that he withdrew his offer to subscribe. The contract was held to have been completed the moment the company's secretary mailed to him the notification of the allotment made him, and his withdrawal of his offer was held ineffectual. The court reviews the case of $B$. \& $A$. Teleg. Co. v. Colson, Law Reports, 6 Exch. 108, and while evidently disapproving that doctrine, yet holds that it decided that the posting of a letter of acceptance, if it arrives, is a complete contract, yet if from any cause, such as a failure of duty by the post office, the letter never arrives at all, then there is a difference.

In 1879 the Court of Appeal decided, Household F. \& $C$. Accident Ins. Co. (Limited) v. Grant, Law Reports, 4 Excq. Div. 2Ig. In that case Baggallay, L. J., speaking for the majority of the court, came to the conclusion that the House of Lords in Duxlop v. Higgins, supra, announced a rule inconsistent with the rule of Colson's case, and that a letter of acceptance duly posted, but never received, completed the contract and bound the parties from the moment of posting exactly as if received at that moment.

In Byme \& Co. v. Van Tienhoven, Law Reports, 5 Com. Pleas Div. 344, the High . Court of Justice in I880 decided an action for damages on this state of facts. The defendant at Cardiff, Wales, wrote to the plaintiff at New York, October I, 1879, offering, 1,000 boxes of tin plates of a named brand, at a certain price, calling for a reply by cable on or before the 
fifteenth here. The acceptance was cabled back October II, and a letter of further acceptance posted October 15. October 8 defendant sent by post to the plaintiffs a withdrawal of the offer of October $\mathrm{I}$. This revocation reached the plaintiffs Occober 20 and so some days after the sending of the telegram and the letter of acceptance. It was claimed that this amounted to a withdrawal of the offer before its acceptance, but the New York house had already resold the tin and insisted upon the performance of the contract. The court declined to follow Pothier and other civilians of celebrity who are of opinion that there can be no contract if an offer is withdrawn before it is accepted, although the withdrawal is not communicated to the person to whom the offer has been made.

It set against that view the opinion expressed by our own Federal Supreme Court in Tayloe .v. M. F. Ins. Co., cited below, that a state of the mind cannot be regarded in dealings between man and man, and that an uncommunicated revocation is, for all practical purposes and in point of law, no revocation at all.

It holds "It may be taken as now settled that where an offer is made and accepted by letters sent through the post, the contract is completed the moment the letter accepting the offer is posted, even though it never reaches its destination." But it holds this rests on the principle that the offerer has expressly or impliedly made the post office his agent to receive the acceptance. That this principle is inapplicable to the withdrawal of an offer because there is no such assent by the other party that the post office should be his agent to receive such withdrawal. That any other rule would leave one who received an offer by post in utter uncertainty whether the contract was closed or not until such time had elapsed as to assure him no letter revoking the offer had been posted prior to his posting his acceptance. The eminent judge (Lindley, now Lord Lindley and Master of the Rolls) concludes that legal principle and practical convenience concur in supporting these views.

The case of Henthorn v. Fraser, Law Reports 2 Ch. (1892) 27, decided in the Court of Appeal in 1892, dealt with a case 
where an offer was not sent by post, but the secretary of a building society handed to the plaintiff, on July I, at Liverpool, a written refusal "of the Flamank street property at $75^{\circ}$ pounds for fourteen days." July 8 the Land Company got an offer of 760 pounds for this property, and the secretary, between I 2 and I o'clock on that day, posted a letter addressed to the plaintiff at Birkenhead withdrawing the previous option. This was delivered to the plaintiff's address between 5 and 6 o'clock that evening, but he was out, and it first reached his hands about 8 o'clock. In the meantime, at $3.50 \mathrm{p}$. m. the same day, the plaintiff by his solicitor at Birnkenhead, had posted an unconditional acceptance of the offer, addressed to the secretary, which acceptance was received the next morning. An action for specific performance of the contract was brought, and the principal opinion by the late gifted Lord Herschell, whose sudden and lamented death in this country is so recent, is a model of lucid reasoning and a complete review of the English authorities to its date. The conclusion is reached that an offer need not be made by post in order to constitute the post office the agent of the offerer to receive the reply. Lord Herschell states the rule thus: "Where the circumstances are such that it must have been within the contemplation of the parties that, according to the ordinary usages of mankind, the post might be used as a means of communicating the acceptarce of an offer, the acceptance is complete as soon as it is posted."

Professor E. T. Holland, in his "Elements of Jurisprudence" (8th ed., p. 237-39), compares the doctrine of various European codes and nations on the subject, exhibits the English rule as above indicated, and shows that upon the Continent views are by no means unanimous.

To turn to the American decisions-

In 1822 the Supreme Court of Massachusetts, in McCulloch v. The Eagle Ins. Co., I Pick. 278, decided that where an offer to insure property was posted January $I$, and followed by a letter retracting the offer on the second, although the reply accepting the offer of January I was posted before the retraction was received, there was no contract. Chief Justice Parker holds the "treaty open" until the accepting letter was received 
by the company, and prior to that the company withdrew its offer.

So that lthus early the Massachusetts court, under the lead of its great chief justice, put itself in conflict with the doctrine of the English court.

In I830 the Court of Errors of New York decided the case of Mactier's Admr. v. Frith, 6 Wend. 103, holding that an offer to sell a cargo of brandy having been sent from Santo Domingo to New York and having been accepted by a letter posted at New York on a certain day, the posting of the letter of acceptance closed the contract, and the death of the acceptor, before his letter reached its ${ }^{-}$destination, did not alter its effect. The opinions rest expressly on Adams v. Lindsell, supra, and Mr. Justice Marcy reviews and contrasts that decision with the conclusion of the Massachusetts court, and testing them by "reason and the practical results that are likely to flow from them," strongly adheres to the English authority.

In I849 the Supreme Court of the United States (Tayloe v. Merchants' F. Ins. Co., 9 How. 390) passed upon the case of a gentleman named Tayloe, who had obtained a proposition by post, from an insurance company, to insure his dwelling on certain terms. The letter reached Mr. Tayloe December 20, and on the next day he accepted by posting a letter to that effect and enclosing his check for the premium, as agreed. A day later, and before his letter had reached its address, a great part of the dwelling was consumed by fire, and the company later refused, on receipt of his letter, to accept the premium or issue the policy. It was held that the contract was complete the moment Mr. Tayloe mailed his letter of acceptance, and the cases of Adams v. Lindsell, I B. \& A. 681, and Mactier v. Frith, 6 Wend. 103, are quoted and adopted in Mr. Justice Nelson's extended and valuable opinion.

In I893 the Supreme Court of the United States, in Patrick v. Brennan, 13 S. C. R. $81 \mathrm{I}$, quoted at length from Tayloe v. Ins. Co., supra, and fully approved its doctrine on the above subject, finding authorities abundant to support it and citing with like approval the kindred English and American cases.

The Court of Appeals of New York, in I867, in Trevor v. 
Wood, 36 N. Y. 307 , held, "Where the offer is by letter or by telegram, the acceptance signified in the same manner is sufficient, irrespective of the time when it comes to the knowledge of the proposing party." The court cites no case dealing with acceptance by telegram but relies on the principles applied to letters by post as entirely analagous.

Attention is there called to the fact that in Mactier v. Frith, 6 Wend. I03, the letter of acceptance was not sent by public post, as " it was to go from New York to Jacmel, in the island of Santo Domingo, between which places no communication was had at that time by mail."

Many other cases are collected and the whole subject admirably reviewed under the title "Letters" and sub title "Contract," I3 Am. \& Eng. Enc. of Law, pp. 233 to 236.

Professor Harriman, in his thoughtful and thorough little hand-book on "Contracts," after calling attention to the English doctrine on this subject, on page 94 says: "The "same rule prevails throughout the United States with the ex" ception of Massachusetts, where an early case laid down the "doctrine that an actual communication of an acceptance is " necessary to complete the contract. There has been much " artificial reasoning on this point caused by a desire on the part " of judges and text writers to make every case harmonize "with the subjective, consensual theory of contract, that there " must be a meeting of minds to constitute a contract. It " would seem as if the simple and straightforward reasoning of "Lord Herschell in Henthorn v. Fraser, the latest English case "on this point, ought to sweep away the fog which has so "long obscured this simple though important question."

He points out that in Alabama the doctrine prevails that when an offer and due acceptance are both sent by mail the contract becomes binding as of the date of the offer, but he deems this a mere judicial vagary. Mr. Harriman had the sagacity and felicity to point out in 1896 that there seemed little doubt that the peculiar doctrine of Massachusetts would be overruled in that State (Harriman on Contracts, p. 94, note), resting his prediction upon Bishop v. Eaton, I61 Mass. 496. which, though inconsistent with the earlier cases, did not review them and discussed the subject rather slightly. His 
prediction seems fulfilled in Brauer v. Shaw, I68 Mass. 198, decided March 29, I897. The facts in that case were as follows: Defendants telegraphed at II.3O a. m. to plaintiff with regard to shipment of cattle by ocean steamer, "subject prompt reply will let you May space fifty-two six." This was received in New York at 12.16 , and at 12.28 a reply was sent accepting the offer. For some reason this was not received by defendant until 1.20. At one o'clock, the defendants telegraphed, revoking their offer and this message was received at 1.43. The court seems to hold the contract completed the moment the acceptance was delivered to the telegraph company and that the message withdrawing the offer was ineffective until it reached the other party and was therefore too late. Judge Holmes, for the court, declines to follow the contrary suggestion in McCulloch v. Eagle Ins. Co., I Pick. 278, and prefers the rule stated in the above English cases and by the Supreme Court of the United States.

Harriman says: "Where the parties have agreed to transact business by telegraph, the contract is completed as soon as the offer is delivered to the telegraph company." Again Professor Harriman (Harriman on Cont., p. 95) observes, "Since the contract is complete when the letter of acceptance is posted, the subsequent fate of the letter is of no consequence."

Sir F. Pollock thinks that Lord Cottenham, in Dunlop v. Higgins, I H. L. Cases $38 \mathrm{r}$, "seems to have thought the con"tract was absolutely concluded by the posting of the accep" tance (within the prescribed or a reasonable time) and that it " mattered not what became of the letter afterwards. It appears "to have been so understood in Duncan v. Topham, 8 C. B. " 225, where, however, discussion was on other grounds." (Poflock on Cont., p. 641.)

Professor Langdell thinks the communication of the acceptance to the offerer is necessary, and until this occurs no contract is made. He says, Langdell Sum. Law Contracts, Section 14, in case of contracts inter prasentes the words or signs must be both heard or seen, in contracts inter absentes the letter must be received and read. His principal and almost only authority for this view is a case decided in 1813 by the Court of Cassation in France, namely, S. v. F. 
D. and others (reported in Merlin de Jurisprudence, Tit. Vente, I, Art. I I I, No. XI, bis.), which may be more conveniently found in Langdell's Cases on Contracts, $156-60$, and is reprinted by Professor Langdell's permission in I Keener's Cases on Cont., 149, where the able and ingenious but almost fanciful argument of Merlin covers six pages, the decree in his favor three lines and a half. Merlin quotes extensively from the pundits of the civil law to support the proposition that a letter of acceptance may be revoked at any time before it comes to the knowledge of the offerer, and he says, "Now it is an elemen"tary maxim that I can recall my agent so long as he has not "executed his mandate." "I can therefore recall the letter " which I have addressed to you so long as it has not reached "you, so long as it has not brought to you the words which "I had given it in charge for you."

He puts the case of a deaf person who offers you goods at a fixed price. You reply that you will take them. He answers that he cannot hear and prays that you will write your answer. You write to him, "I said I would, but on further reflection your proposition is not satisfactory." Merlin urges no one could pretend that you were bound by your spoken acceptance so unheard by the offerer. He also puts the case of one with an acoustic vault with speaking tubes which delay a message spoken in them five minutes. An offer is made by the owner, and the reply accepting is spoken into his speaking tube, but, before the five minutes pass requisite for it to reach his ear, the acceptor countermands it by running to him and speaking directly to him, and he urges that it could not be claimed that the first acceptance in such case bound.

It is submitted that though this reasoning is most ingenious and the situation described perhaps somewhat puzzling, yet, in the matter of treating a letter of acceptance duly mailed, according to the terms of the offer or custom of business in contemplation of the parties, as an agent who has not executed the mandate of his principal he somewhat evades the question.

The courts of England and America have so far taken a different view and, treating the post as the agent of the offerer duly authorized to receive the reply, treat the reply as in the 
offerer's hands as soon as it is in the hands of his agent and that its subsequent loss, delay or miscarriage can have no effect upon the contract, which was consummated at that moment, any more than any other act or omission on the part of one party to a contract, or his agent, except as the other party assents thereto or avails himself thereof. If the suggestion of Professor Langdell that the letter of acceptance must be received and read to complete the contract be adopted, a most inconvenient element of uncertainty would be introduced and an acceptance by writing would always be ineffectual until the acceptor's voluntary act, namely, his reading it, operated in turn as an acceptance of the acceptance. If this is requisite then it must be pleaded and proved in all cases involving such a transaction unless it may be presumed from the proper mailing, even then it may be denied and put in issue and the receipt of the letter by the offerer is of no avail until he sees fit to read the acceptance. The acceptor has no means of knowing this, and cannot, during a length of time, treat the contract as complete. It is submitted, with deference, that the practice of business men is quite the reverse and the rule holding a sale complete on delivery of goods to a common carrier, addressed to the buyer and in accord with his order, strongly supports the view that the acceptance, being posted, closes the contract. If such goods are thereafter destroyed, the loss falls on the consignee, not the consignor. Lord Cottenham, in Dunlop v. Higgins, I H. L. C. $38 \mathrm{I}$, compared the letter of acceptance to one containing notice of dishonor of a bill of exchange. "Whether that "letter be delivered or not is a matter quite immaterial, because "for accidents happening at the post office he is not respon" sible." This with the accompanying discussion has often been considered as a mere dictum, but in Household Ins. Co. v. Grant, L. R. 4 Exch. D. 216, the Court of Appeal speaking through Thesiger, L. J., held that this doctrine was a ratio decidendi in the above decision and so binding upon the English courts, and the majority of the court there hold that an acceptance duly posted binds the offerer whether or not it ever comes to his hand.

Bramwell filed a very vigorous dissent and Sir F. Pollock 
most eminent of English legal scholars, regrets that this dissenting opinion did not prevail, although he holds that the result must be taken as final. (Pollock on Contracts, p. 36.)

A like conclusion had been long before reached by the Court of Appeals of New York in Vassar v. Camp, I I N. Y. 441 , decided in 1854 , where it was held that merchants at Sackett's Harbor, having forwarded by post to a brewer at Poughkeepsie a proposed contract signed by the former in duplicate, for purchase and sale of barley, and the brewer having promptly signed the contract and deposited one of the duplicates so signed in the post office at Poughkeepsie, properly directed to the merchant, that consummated the contract and it was obligatory on the merchants whether they received it or not.

The Supreme Court of Wisconsin, in Washburn v. Fletcher, 42 Wis. 1 52, in 1877 fully adopted the doctrines of the above New York case and held the law well settled in England and this country as there announced.

If the person making the offer fears he may suffer any hardship under this rule, he can adequately protect himself by providing that unless the acceptance reaches his personal knowledge within a fixed time, the same shall have no effect. (Pollock on Cont., ${ }^{*} 36$.) If the rule contended for by Merlin and Professor Langdell were sustained there would be. no equally simple and convenient way for the acceptor to protect himself.

In a rule of this sort, so largely affecting commercial transactions, perhaps clearness, certainty and uniformity are more to be desired than perfect accord with the theory of the meeting of the minds in contracts and perhaps, if either should yield, it is rather this theory than the convenience of commerce.

In the judgment of the majority of the able judges who have considered the rule it is not in conflict with the elementary requirement as to contracts. (See opinion Thesiger, L. J., in Household F. \& C. Ins. Co. v. Grant, L. R., 4 Exch. 216.)

He fully admits the hardship of the rule in some cases, but points out the far more mischievous consequences of the opposite rule. 
The acceptance, of course, will not be consummated by mailing an unstamped letter: Blake v. Hamburg-Brcmen F. I. Co., 35 Albany L. J. 82 ; Britton v. Philips, 24 How. Pr. I I I. And the question of what is such a mailing as will close the contract was quite fully.examined by Mr. Justice CozzensHardy in November last in the Court of Appeals, Chancery Division. See London \& $N$. Bank, In Re, Jones* ex parte, 69 L. J. Ch. $24 ; 8 \mathrm{I} \mathrm{L.} \mathrm{T.} 512$. In that case a letter of allotment of shares was proved to have been delivered at the general post office at $7.30 \mathrm{a} . \mathrm{m}$., by handing the same to a postman met at the entrance of the post office, with a small fee, on his offer to take the same. This letter, however, bore a post mark showing its posting at I I.30 a. m. At $8.30 \mathrm{a} . \mathrm{m}$. a letter withdrawing the offer to subscribe for shares was delivered at the company's office and opened by its secretary at 9.30. It was shown by the postal regulations the postman was prohibited from taking charge of letters. It was decided that, although it is the settled law that an offer is to be deemed accepted when the letter containing the acceptance is posted, and no delay on the part of the post office in delivering the letter will be material, yet, a town postman is not an agent of the post office to receive letters and consequently the delivery to him of a letter of acceptance of an application for allotment of shares will not, for the purpose of fixing the time of the acceptance, be regarded by the court as a posting of the letter.

I add one comparatively late case showing the effect, in construing a contract, produced by the above-rule that a contract is made, not by the offer but by the acceptance, and so at the place the acceptance is mailed. In 1898 in Zeltner v. Irwin, 49 N. Y. Sup. 337 , it was held that the advertising circulars of a stock broker, setting out the advantages of certain methods of dealing and the facilities of the broker, was no such offer as to make the mailing of a letter to him with funds for investment an acceptance. That this letter itself was an offer to contract and if the broker mailed back his acceptance from Pittsburg, $\mathrm{Pa}$., it was this second letter which consummated the contract. Therefore the place of the mailing of this last letter determined the place where the contract was made, and so the law which governed it. That therefore the contract 
above must be governed by the laws of Pennsylvania. It was admitted such a contract was void by New York statutes, but urged that there was no proof that it contravened the Pennsylvania law. The court held that, in the absence of proof, the Pennsylvania law would be presumed to be the common law, which did not invalidate a wagering contract and that this contract, being a Pennsylvania contract, therefore was good where it was made and so binding everywhere.

See this doctrine upheld : 7 Am. \& Eng. Enc. Law (2d ed.), p. 136, citing Cozvan v. O'Connor, $20 \mathrm{Q}$. B. Div. 640, the full syllabus of which is as follows: An order to make certain bets having been telegraphed by postal telegraph from the plaintiff, without the city of London, to the defendant within it, he telegraphed from the city that the order had been obeyed. Held, that the contract of agency was made in the city and that an action for the breach of such contract was within the jurisdiction of the Lord Mayor's Court.

Among the many interesting discussions of this subject two of especial interest are found in 7 Am. Law Review, 433; 8 Am. Law Review, 182.

If the doctrine is taken as settled, as it seems to be in both England and America, that one who makes an offer under such conditions that an answer by post or telegraph is to be contemplated, is bound by the acceptance the moment it is delivered to the postal or telegraph authorities, whatever the later fate of the message, then everyone making such an unqualified offer, in effect, offers to be bound by such acceptance so delivered, and where parties voluntarily submit themselves to a liability they can not complain of any hardship.

The controversy as to the logic of the English and American zule is perhaps further promoted by the postal regulations of this country, which permit the sender of a letter in many cases, on proper proceedings, to recall his letter after mailing at any time before delivery. However, if the moment of posting consummates the contract, then the subsequent act of one party, it is submitted, can not dissolve it. The acceptor has done that which, the terms of the offer or the customs of business which a court reads into the offer, have indicated would 
COMPLETION OF CONTRACTS BY MAIL OR TELEGRAPH. 367

be sufficient to fix the liability as by an acceptance directly communicated. The offerer in effect says: "Hand your acceptance to the postal authorities, they are my agents to receive it." That being so, on such delivery the offerer is bound. He has received the acceptance. Facit per alium facit per se.

College of Law,

Charles Noble Gregory.

University of Wisconsin. 